\title{
Distribution of the stx1 and stx2 genes in Escherichia coli isolated from milk cattle according to season, age, and production scale in southwestern region of Goiás, Brazil
}

[Distribuição dos genes stx1 e stx2 em Escherichia coli isoladas de bovinos de leite de acordo com a estação, idade e escala de produção na região sudoeste de Goiás, Brasil]

\author{
M.R.A. Ferreira ${ }^{1,2}$, A.E. Stella ${ }^{1}$, E.G. Freitas-Filho ${ }^{1,3}$, T.S. Silva ${ }^{1}$, K.A. Nascimento ${ }^{1,4}$, \\ J.F.N. Pinto ${ }^{1}$, M. Dias ${ }^{1}$, C.N. Moreira ${ }^{1 *}$ \\ ${ }^{1}$ Universidade Federal de Goiás - Jataí, GO \\ ${ }^{2}$ Universidade Federal de Pelotas - Pelotas, RS \\ ${ }^{3}$ Universidade de São Paulo - São Paulo, SP \\ ${ }^{4}$ Universidade Estadual Paulista "Júlio de Mesquita Filho" - Jaboticabal, SP
}

\begin{abstract}
This study determined the distribution of stx 1 and stx2 genes in Escherichia coli isolated from dairy herds with regard to animal age, season, and farm production-scale, and analyzed the phylogenetic distribution of the groups A, B1, B2, and D of 276 isolates of bovine feces Shiga toxin-producing E. coli (STEC). The stxl profile was the most common, detected in $20.4 \%$ (202/990) of the isolates, followed by stx2 $(4.54 \%, 45 / 990)$ and stx $1+s t x 2(2.92 \%, 29 / 990)$. The stxl gene was detected more frequently in calves than in adult animals. In the dry season (winter), the presence of stx $1+s t x 2$ profile in cattle feces was higher than in the rainy season (summer), while no significant changes were observed between seasons for the stx 1 and stx 2 profiles. The most predominant phylogenetic groups in adult animals were B1, A, and D, while groups A and B1 prevailed in calves. Our data highlight the importance of identifying STEC reservoirs, since $7.5 \%$ of the tested isolates were positive for stx2, the main profile responsible for the hemolytic-uremic syndrome (HUS). Moreover, these microorganisms are adapted to survive even in hostile environments and can contaminate the food production chain, posing a significant risk to consumers of animal products.
\end{abstract}

Keywords: Shiga toxin-producing Escherichia coli (STEC), phylogenetic STEC groups, STEC reservoirs; Stx1, Stx2

\section{RESUMO}

Esse estudo determinou a distribuição dos genes stx1 e stx2 em Escherichia coli isolados de rebanhos leiteiros em relação a idade, estação e produção, e analisaram a distribuição filogenética dos grupos A, B1, B2 e D de 276 E. coli produtoras de toxina Shiga (STEC). O perfil stx1 foi mais comum, detectado em 20,4\% (202/990) dos isolados, seguido de stx2 (4,54\%, 45/990) e stx1+stx2 (2,92\%, 29/990). O gene stx 1 foi detectado mais frequentemente em bezerros que animais adultos. No período de seca (inverno), a presença do perfil stx1+stx2 nas fezes dos bovinos foi mais prevalente que no período chuvoso (verão), apesar de não haver diferença significativa entre estações para os perfis stx1 e stx2. Os grupos filogenéticos mais predominantes em animais adultos foram $B 1, A$ e $D$, enquanto grupos $A$ e $B 2$ prevaleceram em bezerros. Nossos dados enfatizam a importância de se detectar reservatórios de STEC já que 7,5\% dos isolados testados foram positivos para stx2, o perfil mais prevalente em casos de síndrome hemolítica-urêmica. Ademais, esses microorganismos são adaptados à sobreviver em ambientes hostis e contaminam a cadeia alimentar, levando a risco significativo para consumidores de alimentos de origem animal.

Palavras-chave: Escherichia coli produtora de toxina shiga (STEC), grupos STEC filogenéticos, reservatórios STEC, Stx1, Stx2

Recebido em 29 de março de 2017

Aceito em 17 de abril de 2018

* Autor para correspondência (corresponding author)

E-mail: cissanm@yahoo.com.br 


\section{INTRODUCTION}

Enteric disease-inducing Escherichia coli have been divided into pathotypes, based on their virulence factors and disease-causing mechanisms (Farrokh et al., 2013). Despite of this fact, the potent cytotoxic produced strains known as Shiga toxin (Stx) are defined as STEC (Shiga toxin-producing Escherichia coli) (Nataro and Kaper, 1998). STEC strains can cause hemorrhagic colitis (HC) and the hemolyticuremic syndrome (HUS), which have been related to the consumption of different types of foods, especially of bovine products. Healthy beef or dairy cattle are the largest reservoirs of several serotypes of STEC, including the serotypes O157 and non-O157 serotypes, and can be transmitted through contaminated water or food and by direct contact with feces of animal carriers (Chiang et al., 2011).

In cattle, STEC colonize the intestinal epithelium, especially in the mucosa adjacent to the anorectal junction, where they are present as commensal microbiota without causing damage to the host (Bolton, 2011). Apart from other factors, such as animal age, sex, and nutrition, the main factor repeatedly indicated as influencing the occurrence of STEC in feces is seasonality (Fernández et al., 2009; Jeon et al., 2013; Ferreira et al., 2014). The elimination in feces decreases dramatically in fall and winter, increases in spring, and peaks in the summer months (Van Donkersgoed et al., 1999; Arthur et al., 2009).

Stx 1 is a similar cytotoxin to that produced by Shigella dysenteriae serotype 1, but antigenically distinct (O'Brien and Holmes, 1987). The Stx2 cytotoxin has little similarity to Stx1 and Shiga toxin (Stx) from $S$. dysenteriae type 1. Also, Stx2 cannot be recognized and neutralized by the antibodies against the latter two cytotoxin (Scheutz et al., 2012). Stx1 and Stx2 are also known as verotoxins (VT), and in this study, cytotoxicity was tested in Vero cells derived from African green monkey kidney (Cercopithecus aethiops; Konowalchuk et al., 1977). The most important STEC subgroup contains the called strains enterohemorrhagic $E$. coli (EHEC) (Nataro and Kaper, 1998). EHEC subgroup is able to colonize the human intestinal mucosa and produce an effacing lesion by a type III secretion system (McDaniel et al., 1995;
Kaper et al., 2004). This subgroup is an important etiologic agent of diseases in humans, including diarrhea, HC, HUS and renal insufficiency (Repetto, 20005; Karch et al., 2005).

The state of Goiás plays an important role in dairy farming in Brazil and is currently ranked as the sixth largest milk-producing state of the country (IBGE, 2017). Since cattle is the main reservoir of STEC, it is important to understand the potential pathogenic risk of STEC isolates and their impact on public health in the state supply chain. Previously, other studies described the prevalence of STEC isolated from healthy cattle in 34 dairy farms localized in the southwestern region of Goiás state, Brazil. It was also evaluated the main risk factors for STEC infection (Freitas-Filho et al., 2014; Ferreira et $a l ., 2014)$. The aim of the present study was to evaluate the distribution of stx 1 and stx 2 genes in $E$. coli isolated from healthy cattle, taking into account the season, animal age, and farm production scale, as well as to analyze the pathogenic potential of isolated STEC by the phylogenetic classification (Clermont et al., 2000).

\section{MATERIAL AND METHODS}

Nine hundred and ninety $E$. coli isolates used in this study were obtained from stool samples of healthy cattle (198 animals) from 34 dairy farms located in the municipality of Jataí, Goiás, Brazil. The 34 farms were divided into three production-scale groups: Low output (100L/milk/day); medium output (100 to 400L/milk/day); and high output (overt to 400L/milk/day). Rectal swab samples were collected and placed in Stuart transport medium (Mumbai, India). The samples were inoculated on MacConkey agar and incubated for $24 \mathrm{~h}$ at $37^{\circ} \mathrm{C}$. Colonies with growth characteristics of $E$. coli (five per plate) were subcultured and identified by biochemical tests of lactose fermentation, indole production, methyl-red and Voges-Proskauer reactions, citrate utilization, urease production, and by the production of hydrogen sulphide $\left(\mathrm{H}_{2} \mathrm{~S}\right)$.

Whole-cell DNA was extracted as previously described (Keskimaki et al., 2001). The PCR reactions were performed in a total volume of $25 \mu \mathrm{L}$ mixture with $2.5 \mu \mathrm{L}$ of the extracted DNA, 
$10 \mathrm{pmol}$ of each primer: universal primer 16SrRNA (internal control) forward (F) (5'CCCCCTGGACGAAGACTGAC-3') and reverse (R) (5'-ACCGCTGGCAACAAAGGATA-3'); stxl-F (5'TCTCAGTGGGCGTTCTTATG-3') and stxl-R (5'TACCCCCTCAACTGCTAATA-3') (Wang et al., 2002); st $x 2$-F (5'-GGCACTGTCTGAAACTGCTCC-3') and stx2-R (5'-GGCACTGTCTGAAACTGCTCC-3') (Paton and Paton, 1998); and GoTaq ${ }^{\circledR}$ DNA polymerase following manufacturer's instructions (Promega, Madison, Wisconsin, USA). E. coli O157:H7 EDL933 and Klebsiella pneumoniae ATCC BAA 1705 were used as positive and negative controls, respectively.

The phylogenetic groups were determined in simultaneous amplification tests (PCR-triplex) to identify the genes $c h u A, y j a A$ and fragment TspE4.C2. The oligonucleotide pairs used were chuA-F (5'-GACGAACCAACGGTCAGGAT-3') and chuA-R (5'-TGCCGCCAGTACCAAAGACA-3'), yjaAF (5'-TGAAGTGTCAGGAGACGCTG-3') and yjaA-R (5'-ATGGAGAATGCGTTCCTCAAC-3'), and TspE4.C2F (5'-GAGTAATGTCGGGGCATTCA-3') and TspE4.C2-R (5'-CGCGCCAACAAAGTATTACG-3'). The groups B2 $\left(\right.$ chuA $\left.A^{+} / y j a A^{+}\right), \mathrm{D}\left(\right.$ chuA $\left.^{+} / y j a A^{-}\right)$, B1 (chuA-/TspE4.C2 $\left.{ }^{+}\right)$, and A (chuA-/TspE4.C2 ) were classified phylogenetically, as proposed by to Clermont et al. (2000). Comparative statistical data analysis was performed by Fisher's exact test.

In the analysis of possible risk factors for STEC presence in cattle, all data were analyzed using the Statistical Analysis System ("Statistical..., 2010) v.9.0, at $5 \%$ probability. The effects of animal age, season, and farm output scale on STEC occurrence were analyzed by logistic regression with dichotomous response, using the
Wald and odds ratio tests, considering all effects in the full model, with subsequent modeling, after eliminating the non-significant effects.

The study procedures were carried out and the animals treated according to international standards and in compliance with the ethical principles of animal experimentation established by the Colégio Brasileiro de Experimentação Animal (COBEA) (protocol: 206/2009/COEP/ PRPPG/UFG).

\section{RESULTS}

The genotyping of the $990 \mathrm{E}$. coli isolates showed that $27.9 \%(276 / 990)$ of the isolates carried one or more of the investigated stx 1 and/or stx 2 genes. stx 1 profile was the most common and was presented in $20.4 \%(202 / 990)$ of the isolates, followed by stx $2(4.54 \% ; 45 / 990)$ and stx $1+s t x 2$ profile $(2.92 \% ; 29 / 990)$. The percentage of STEC-carrying animals was $45.4 \%$ (90/198). The target profiles were detected more frequently in calves than in adult animals, although the variability was not significant (Table 1). The season had an influence in STEC prevalence. The $s t x 1+s t x 2$ profile demonstrated higher percentage in cattle isolates in the dry season (winter) than in the rainy season (summer), while no significant changes between seasons were observed for stx 1 and stx 2 profiles analysis.

The 276 STEC strains were divided into four groups (B2, D, B1, and A) by phylogenetic characterization and distributed according to the season and animal age (Table 2). The pathogenic group D was most prevalent in the winter season. There was no difference between the profile distribution of phylogenetic groups in cows and calves.

Table 1. Prevalence of Escherichia coli isolated from dairy cattle, carrying stx1, stx2 or stxl+stx2 genes, according to the age, season and farm production scale

\begin{tabular}{ccccccccc}
\hline stx genotype & \multicolumn{2}{c}{ AGE $^{\mathrm{a}}$} & \multicolumn{2}{c}{ Season $^{\mathrm{a}, \mathrm{b}}$} & \multicolumn{2}{c}{ Farm Production Scale } & \multicolumn{2}{c}{ Total } \\
\hline stx 1 & Cow & Calf & Winter & Summer & Low & Medium & High & \\
stx 2 & 60 & 142 & 91 & 111 & $95 \mathrm{~A}$ & $91 \mathrm{~A}$ & $16 \mathrm{~B}$ & 202 \\
stx $1+$ st $x 2$ & 15 & 30 & 24 & 21 & $19 \mathrm{~A}$ & $21 \mathrm{~A}$ & $5 \mathrm{~B}$ & 45 \\
Total & 5 & 24 & $21 \mathrm{~A}$ & $8 \mathrm{~B}$ & $21 \mathrm{~A}$ & $8 \mathrm{~B}$ & $0 \mathrm{C}$ & 29 \\
\hline & 80 & 196 & 136 & 140 & 135 & 120 & 21 & 276 \\
\hline
\end{tabular}

${ }^{a}$ Non-significant $(\mathrm{P}>0.01)$ for all genes according to the animal age, and for stxl and stx2 genes according to the season.

${ }^{\mathrm{b}}$ Different letters in a row indicate significantly different $(\mathrm{P}<0.01)$, and same letters in a row statistically non significantly different values. 
Table 2. Prevalence of the phylogenetic groups B2, D, B1, and A of STEC strains isolated from dairy cattle, according to the season and animal age

\begin{tabular}{cccccc}
\hline \multirow{2}{*}{ Phylogenetic group } & \multicolumn{2}{c}{ SEASON } & \multicolumn{2}{c}{ AGE } & \multirow{2}{*}{ Total } \\
\cline { 2 - 4 } & Summer & Winter & Cow & Calf & \\
\hline Group B2 $\left(\right.$ chuA $\left.A^{+} / y j a A^{+}\right)$ & 2 & 0 & 1 & 1 & 2 \\
Group D $\left(\right.$ chuA $\left./ y j a A^{-}\right)$ & 11 & 51 & 18 & 44 & 62 \\
Group B1 $\left(\right.$ chuA $/ T$ TspE4.C2 $\left.2^{+}\right)$ & 76 & 54 & 43 & 87 & 130 \\
Group A $\left(\right.$ chuA $\left./ T s p E 4 . C 2^{-}\right)$ & 51 & 31 & 18 & 64 & 82 \\
Total & 140 & 136 & 80 & 196 & 276 \\
\hline
\end{tabular}

\section{DISCUSSION}

Some STEC serotypes can induce human diseases, although not all serotypes found in cattle or foods are associated with severe disease in humans. Several STEC outbreaks have been reported, and one fatal occurred in Sakayin, Japan, in July 1996, with 8,000 cases and 6 deaths (Vidovic et al., 2011). In the present study, an extremely high number of STECcarrying animals (45.4\%) was detected. The rates of prevalence in cattle have been determined for decades; however, comparisons between these studies are hampered by the differences in sampling and methodologies (Chase-Topping $e t$ al., 2008).

Some factors that contribute to the presence and spread of STEC in a herd are the management practices, stress, diet, population density, geographic region, and season (Fernández et al., 2009; Jeon et al., 2013; Ferreira et al., 2014). The seasonal pattern with peaks in the summer leads to a similar variation in the human disease associated with the agent (Ostroff et al., 1989). However, in the present study, a greater isolation of STEC was detected in the winter (dry season), contrasting with Dunn et al. (2004), whom reported a higher STEC frequency in the summer and lower frequency in the winter. The greater presence of isolates carrying both stxl and stx2 genes in the cold and dry months can be related to the pathogenicity, once better adapted strains to cold and drought stress could be more adapted to survive in hostile environments (Allen et al., 2008), e.g., in refrigerated foods of animal origin. Foods of animal origin (milk and meat) were identified as the most important source of STEC entry into the food chain (Martin and Beutin, 2011). In cattle stool samples analyzed at slaughter in an abattoir, Fukushima and Seki (2004) determined a prevalence of $37.5 \%$ of STEC isolates.
The present study demonstrated that young animals could be major source of STEC excretion in the environment. The same conclusion was also demonstrated by Werber $e t$ al. (2007), who stated that young animals have a greater prevalence of colonization with stx profiles of STEC than adult animals, and the prevalence in calves older than two months is higher than in younger calves. The results of $70.3 \%$ stxl-positive isolates and $29.7 \%$ stx 2 positive isolates found in the present study confirmed the findings demonstrated by Andrade et al. (2012) and Vargas-Jr et al. (2017) in healthy calves in, respectively, Minas Gerais and Rio Grande do Sul states, Brazil.

Our data identified a significantly higher percentage $(92.4 \%$; $255 / 276)$ of all investigated STEC strains in cattle excretion on the medium and small-scale farms. These results demonstrate that the inspection of products derived from these farms needs to be intensified, despite of the increased contamination pressure of milk as well as of meat (Martin and Beutin, 2011). It was also reported that STEC prevalence is greater in food from organic than from conventional farms. This is a matter of concern, because STEC, as much as non-pathogenic E. coli, are components of the normal intestinal flora of cattle and the effect of any treatment to control STEC excretion would be limited (Gill and Gill, 2010).

Studies have shown that extraintestinal pathogenic E. coli normally belong to groups B2 and $\mathrm{D}$, whereas pathogenic isolates are classified as groups A, B1 and D (Pupo et al., 1997; Picard et al., 1999). The data of our study show that group B1 was predominant $(54.3 \%)$ in the summer, followed by groups A, D and B2 (with $36.4 \%, 7.8 \%$ and $1.4 \%$, respectively). In winter, there was similarity between B1 $(39.7 \%)$ and D (37.5\%), with lower prevalence of group A (22.8\%), while no B2 isolates were found. Previously, studies done by Escobar-Páramo et 
al. (2004) showed that the prevalence of group B2 was greater in the temperate regions of France than in tropical countries such as Benin, French Guyana and Colombia. The higher prevalence of B1 groups in both periods confirmed the findings demonstrated by Unno et al. (2009), whom reported a higher prevalence of this group in their study. However, our study contradicts the hypothesis that $E$. coli isolates from tropical areas belong mostly to group A (Escobar-Páramo et al., 2004), since in the tropical southeastern region of Brazil, the prevalence of group B1 was higher in both summer and winter, and the prevalence of group A increased in the colder season.

Correlating the phylogenetic groups with the animal age, the prevalence of isolates from adult animals was highest for group B1 (53.8\%), followed by group A (22.5\%), and the prevalence of group D isolates was similar in both age categories $(22.5 \%)$. In calves as well as in adult animals, there was a higher prevalence of group B1 (44.4\%), followed by group A $(32.6 \%)$. In phylogenetic studies of STEC/EHEC/eae $e^{+}$isolates, Tramuta et al. (2008) also observed a higher prevalence of group B1 (38.7\%), followed by group A $(35.5 \%)$ in calves. Similar data were obtained in the study carried from Minas Gerais state, Brazil. Coura et al. (2017) demonstrated that STEC and EHEC isolates from healthy and diarrheic calf feces belonged mainly to phylogenetic groups B1 and A.

Our data highlight the importance of pathogenic E. coli reservoirs, since $7.5 \%$ of the tested isolates were positive for $s t x 2$, which is mainly responsible for HUS. Moreover, these microorganisms, adapted to survive in hostile environments, with significant levels of pathogenic strains excreted in the colder and dry months, can reach the food production chain, representing a significant risk to consumers of animal products.

\section{ACKNOWLEDGEMENTS}

The authors are indebted to the farm owners and workers for their generous assistance and cooperation with sampling. This study was supported by the grant 503886/2009-2 from Conselho Nacional de Desenvolvimento Científico e Tecnológico (CNPq).

\section{REFERENCES}

ALLEN, K.J.; LEPP, D.; MCKELLAR, R.C.; GRIFFITHS, M.W. Examination of stress and virulence gene expression in Escherichia coli O157:H7 using targeted microarray analysis. Foodborne Pathog. Dis., v.5, p.437-447, 2008.

ANDRADE, G.I.; COURA, F.M.; SANTOS, E.L.S. et al. Identification of virulence factors by multiplex PCR in Escherichia coli isolated from calves in Minas Gerais, Brazil. Trop. Anim. Health Prod., v.44, p.1783-1790, 2012.

ARTHUR, T.M.; KEEN, J.E.; BOSILEVAC, J.M. et al. Longitudinal study of Escherichia coli O157:H7 in a beef cattle feedlot and role of highlevel shedders in hide contamination. Appl. Environ. Microbiol., v.75, p.6515-6523, 2009.

BOLTON, D.J. Verocytotoxigenic (Shiga Toxin-Producing) Escherichia coli: virulence factors and pathogenicity in the farm to fork paradigm. Foodborne Pathog. Dis., v.8, p.357$65,2011$.

CHASE-TOPPING, M.; GALLY, D.; LOW, C. et al. Super-shedding and the link between human infection and livestock carriage of Escherichia coli O157. Nat. Rev. Microbiol., v.6, p.904-912, 2008.

CHIANG, S.M.; DONG, T.; EDGE, T.A.; SCHELLHORN, H.E. Phenotypic diversity caused by differential Rpos activity among environmental Escherichia coli isolates. Appl. Environ. Microbiol., v.77, p.7915-7923, 2011.

CLERMONT, O.; BONACORSI, S.; BINGEN, E. Rapid and simple determination of the Escherichia coli phylogenetic group. Appl. Environ. Microbiol., v.66, p.4555-4558, 2000.

COURA, F.M.; DINIZ, S.A.; MUSSI, J.M.S. et al. Characterization of virulence factors and phylogenetic group determination of Escherichia coli isolated from diarrheic and non-diarrheic calves from Brazil. Folia Microbiol., v.62, p.139-144, 2017.

DUNN, J.R.; KEEN, J.E.; THOMPSON, R.A. Prevalence of shiga-toxigenic Escherichia coli O157:H7 in adult dairy cattle. J. Am. Vet. Med. Assoc., v.224, p.1151-1158, 2004. ESCOBARPÁRAMO, P.; GRENET, K.; LE MENAC'H, A. et al. Large-scale population structure of human commensal Escherichia coli isolates. Appl. Environ. Microbiol., v.70, p.5698-5700, 2004. 
Instituto Brasileiro de Geografia e Estatística, 2017. Estatística de produção pecuária. [Rio de Janeiro]. Disponível em: $<\mathrm{ftp}$ //ftp.ibge.gov.br/Producao_Pecuaria/Fascicu lo_Indicadores_IBGE/abate-leite-couro-

ovos_201701caderno.pdf>. Acessado em: 12 jan. 2018.

FARROKH, C.; JORDAN, K.; AUVRAY, F. et al. Review of Shiga-toxin-producing Escherichia coli (STEC) and their significance in dairy production. Int. J. Food Microbiol., v.162, p.190$212,2013$.

FERNÁNDEZ， D.; RODRÍGUEZ， E.M.; ARROYO, G.H. et al. Seasonal variation of Shiga toxin-encoding genes (stx) and detection of E. coli $\mathrm{O} 157$ in dairy cattle from Argentina. $J$. Appl. Microbiol., v.106, p.1260-1267, 2009.

FERREIRA, M.R.A.; FILHO-FREITAS, E.G.; PINTO, J.F.N. et al. Isolation, prevalence, and risk factors for infection by shiga toxinproducing Escherichia coli (STEC) in dairy cattle. Trop. Anim. Health Prod., v.46, p.635639, 2014

FREITAS FILHO, E.G.; FERREIRA, M.R.A.; PINTO, J.F.N.; CONCEIÇÃO, F.R.; MOREIRA, C.N. Enterohemorrhagic Escherichia coli O157:H7 from healthy dairy cattle in Mid-West Brazil: occurrence and molecular characterization. Braz. J. Vet. Res., v.34, p.24-28, 2014.

FUKUSHIMA, H.; SEKI, R. High numbers of Shiga toxin-producing Escherichia coli found in bovine faeces collected at slaughter in Japan. FEMS Microbiol. Lett., v.238, p.189-197, 2004.

GILL, A.; GILL, C.O. Non-O157 verotoxigenic Escherichia coli and beef: a Canadian perspective. Can. J. Vet. Res., v.74, p.161-169, 2010.

JEON, S.J.; ELZO, M.; DILORENZO, N. et al. Evaluation of animal genetic and physiological factors that affect the prevalence of Escherichia coli $\mathrm{O} 157$ in cattle. PlosOne, v.8, p.e55728, 2013.

KAPER, J.B.; NATARO, J.P.; MOBLEY, H.L. Pathogenic Escherichia coli. Nat. Rev. Microbiol., v.2, p.123-40, 2004.
KARCH, H.; TARR, P.I.; BIELASZEWSKA, M. Enterohaemorrhagic Escherichia coli in human medicine. Int. J. Med. Microbiol., v.295, p.405-418, 2005.

KESKIMAKI, M.; EKLUND, M.; PERSONEN, H. et al. EPEC, EAEC and STEC in stool specimens: prevalence and molecular epidemiology of isolates. Diagn. Microbiol. Infect. Dis., v.40, p.151-156, 2001.

KONOWALCHUK, J.; SPIERS, J.L.; STARVIC, S. Vero response to a cytotoxin of Escherichia coli. Infect. Immun., v.18, p.775779, 1977.

MARTIN, A.; BEUTIN, L. Characteristics of shiga toxin-producing Escherichia coli from meat and milk products of different origins and association with food producing animals as main contamination sources. J. Food Protect., v.146, p.99-104, 2011.

MCDANIEL, T.K.; JARVIS, K.G.; DONNENBERG, M.S.; KAPER, J.B. A genetic locus of enterocyte effacement conserved among diverse enterobacterial pathogens. Proc. Natl. Acad. Sci. USA, v.92, p.1664-1668, 1995.

NATARO, J.P.; KAPER, J.B. Diarrheagenic Escherichia coli. Clin. Microbiol. Rev., v.11, p.142-201, 1998.

O'BRIEN, A.D.; HOLMES, R.K. Shiga and Shiga-like toxins. Microbiol. Rev., v.51, p.206220, 1987.

OSTROFF, S.M.; KOBAYASHI, J.M.; LEWIS, J.H. Infection with Escherichia coli $\mathrm{O} 157: \mathrm{H} 7$ in Washington State. The first year of statewide disease surveillance. J. Am. Med. Assoc., v.262, p.355-359, 1989.

PATON, A.W.; PATON, J.C. Detection and characterization of shiga toxigenic Escherichia coli by using multiplex PCR assays for $s t x 1$, stx 2 , eae A, enterohemorragic E. coli hlyA, rfb $b_{o 111}$ and

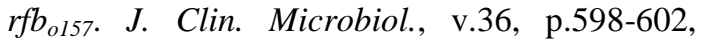
1998.

PICARD, B.; GARCIA, J.S.; GOURIOU, S. et al. The link between phylogeny and virulence in Escherichia coli extraintestinal infection. Infect. Immun., v.67, p.546-553, 1999. 
PUPO, G.M.; KARAOLIS, D.K.R.; LAN, R.; REEVES, P.R. Evolutionary relationships among pathogenic and nonpathogenic Escherichia coli strains inferred from multilocus enzyme electrophoresis and mdh sequence studies. Infect. Immun., v.65, p.2685-2692, 1997.

REPETTO, H.A. Long-term course and mechanisms of progression of renal disease in hemolytic uremic syndrome. Kidney Int., v.68, Suppl.97, p.102-106, 2005.

SCHEUTZ, F.; TEEL, L.D.; BEUTIN, L.; PIÉRARD, D. et al. Multicenter evaluation of a sequence-based protocol for subtyping Shiga toxins and standardizing Stx nomenclature. $J$. Clin. Microbiol., v.50, p.2951-2963, 2012.

STATISTICAL analysis system. Version 9.0. Cari: SAS, 2010.

TRAMUTA, C.; ROBINO, P.; NEBBIA, P. Phylogenetic back- ground of attaching and effacing Escherichia coli isolates from animals. Vet. Res. Commun., v.32, p.433-437, 2008.

UNNO, T.; HAN, D.; JANG, J.; LEE, S. et al. Absence of Escherichia coli phylogenetic group B2 strains in humans and domesticated animals from Jeonnam province, Republic of Korea. Appl. Environ. Microbiol., v.75, p.5659-5666, 2009.
VAN DONKERSGOED, J.; GRAHAM, T.; GANNON, V. The prevalence of verotoxins, Escherichia coli O157:H7, and Salmonella in the feces and rumen of cattle at processing. Can. Vet. J., v.40, p.332-338, 1999.

VARGAS-JÚNIOR， S.F.; CUNHA， R.C.; PEREIRA, D.I.B. et al. Identificação de fatores de virulência de isolados de Escherichia coli oriundos de fezes de bezerros na região Sul do Brasil. Acta Sci. Vet., v.45, p.1467, 2017.

VIDOVIC, S.; MANGALAPPALLI-ILLATHU, A.K.; KORBER, D.R. Prolonged cold stress response of Escherichia coli $\mathrm{O} 157$ and the role of RpoS. Int. J. Food Microbiol., v.146, p.163169, 2011.

WANG, G.; CLARK, C.G.; RODGER, F.G. Detection in Escherichia coli of the genes encoding the major virulence factors, the genes defining the 0157:H7 serotype, and components of the type 2 Shiga toxin family by Multiplex PCR. J. Clin. Microbiol., v.40, p.3613-3619, 2002.

WERBER, D.; BEHNKE, S.C.; FRUTH, A. et al. Shiga toxin-producing Escherichia coli infection in Germany-different risk factors for different age groups. Am. J. Epidemiol., v.165, p.425-434, 2007. 